\title{
Comparison between two Learning Management Systems: Moodle and Blackboard
}

\author{
Alaa M. Momani \\ a.momani@uoh.edu.sa \\ Department of Computer Science, University of Hail, Hail, Saudi Arabia \\ May 13, 2010
}

\begin{abstract}
Moodle and Blackboard are two of the most famous and widely-known Learning Management Systems (LMS) over the world especially in the universities and other educational organizations. They have lots in common, but also have some key differences which make each one special in its own way. We note these differences below. If you have used any one of them before, this document will help you understand the other.
\end{abstract}

\section{Introduction}

This comparison stands on fifty two (52) comprehensive features classified to six main factors which are:
A. Pedagogical Factor,
B. Learner Environment,
C. Instructor Tools,
D. Course and Curriculum Design,
E. Administrator Tools,
F. Technical Specification.

Taking into consideration, the technical and user view-points in describing each feature of each LMS. Hereinafter, there are some general and historical information about each one of them.

\section{Moodle}

Moodle is an open source community launched in 2001 that has grown out of a $\mathrm{PhD}$ research project by Martin Dougiamas. Version 1.0 was released on August 20, 2002. Moodle.com is a company launched in 2003 that sponsors Moodle development and provides commercial support, hosting, custom development, and consulting. The Moodle Partners are a network of companies that work with Moodle.com to provide services around the world. In September 2007, there were 69 Moodle installations with 20,000 or more users. The Moodle trust hires core programmers and covers project expenses. Moodle is perceived as high value in the education community, particularly higher education and further education.

Moodle is one of the most user-friendly and flexible open source courseware products available. It has excellent documentation, strong support for security and administration, and is evolving towards Instructional Management Systems/ Shareable Content Object Reference Model (IMS/SCORM) standards with platform (Apache, PHP, and MySQL). The key to Moodle is that it is developed with both pedagogy and technology in mind. Great with languages although some development may be needed for robust handling of MathML and enhanced tracking features. Still, this program receives a high recommendation. Moodle is a student-centered CMS designed to help educators who want to create quality online courses. The software is used all over the world by universities, schools, companies and independent teachers (Catalyst IT Limited, 2003).

The software helps educators to create online courses and administer them to their students. With Moodle, teachers can format the courses they created in different ways, and integrate lessons with collaborative activities such as workshops and glossaries.

\section{Blackboard}

Blackboard Inc., based in Washington, D.C. (USA) is the creator of a wide variety of software products and services for education programs. Blackboard Learning System is a course management system (CMS) allowing instructors to create or upload teaching and assessing material (e.g. lessons, discussions and assignments) and determines when students can access it. 
As a consequence to Blackboard's widespread use, pre-packaged course materials are provided by all major education publishers. Furthermore the system supports external content respecting the SCORM standard. Students can follow the lessons on-line, interact with the teachers, and with each other in different ways and access repositories of documents. In the University of Gävle, the system is used by the students of more than 120 classes, attending both distance and on location courses.

Blackboard has many clients in the US public service, and has close ties with the Department of Defense through work with the National Defense University and the ADL Co-Lab which implements the Defense Department's Advanced Distributed Learning initiative. The aim is to harness the power of information technology to modernize structured learning.

$\begin{array}{ll}\text { Product Name: } & \text { Moodle } \\ \text { Company: } & \text { Moodle } \\ \text { URL: } & \text { http://www.moodle.org/ } \\ \text { Developer: } & \text { Moodle.org } \\ \text { Contact Developer: } & \text { http://moodle.com/helpdesk/ }\end{array}$

\begin{tabular}{l|l} 
Feature Name & Description \\
\hline
\end{tabular}

\begin{tabular}{|l|l|}
\hline A. Pedagogical Factor (learner and instructor view): \\
\hline $\begin{array}{l}\text { View course } \\
\text { objectives: }\end{array}$ & $\begin{array}{l}\text { It offers a frame to view the course objectives. Instructors can assign the objectives } \\
\text { for each course they instruct. }\end{array}$ \\
\hline $\begin{array}{l}\text { View course } \\
\text { activities: }\end{array}$ & $\begin{array}{l}\text { It offers a frame to view the course activities. Instructors can assign the activities } \\
\text { that should be done by students for each course they instruct. }\end{array}$ \\
\hline Feedback for users: & $\begin{array}{l}\text { The Feedback module allows you to create and conduct surveys to collect feedback } \\
\text { from Students. It is smaller in scope and therefore easier to use than the } \\
\text { Questionnaire module, and unlike the Survey tool allows you to write your own } \\
\text { questions, rather than choose from a list of pre-written survey instruments. It is } \\
\text { currently an optional module though it may become part of the standard install for } \\
\text { version 2.0 of Moodle. Teacher feedback is appended to the assignment page for } \\
\text { each student, and notification is mailed out. }\end{array}$ \\
\hline $\begin{array}{l}\text { Self-assessing for } \\
\text { students: }\end{array}$ & $\begin{array}{l}\text { Instructors can create self-assessments for all students in his/her own courses. } \\
\text { Students can upload their assignments (any file format) to the server -they are date- } \\
\text { stamped. Late assignments are allowed, but the amount of lateness is shown clearly } \\
\text { to the teacher. Advanced assignments can allow multiple files to be uploaded. This } \\
\text { could keep together preplanning maps, outlines, research papers and presentations. } \\
\text { (Not for beginners). }\end{array}$ \\
\hline $\begin{array}{l}\text { Students' progress } \\
\text { tracking and } \\
\text { monitoring for } \\
\text { teachers: }\end{array}$ & $\begin{array}{l}\text { Instructors can track the frequency and duration of student access to individual } \\
\text { course components. Instructors can get reports showing the number of times, time, } \\
\text { date, frequency and IP address of each student who accessed course content, } \\
\text { discussion forums, course assessments, and assignments. Instructors can review the } \\
\text { navigation record of each student. }\end{array}$ \\
\hline
\end{tabular}

\section{B. Learner Environment:}

\section{Communication}

Synchronous:

Real-time chat room: $\quad$ The chat tool supports unlimited simultaneous group discussions. Students can create new rooms. The system creates archive logs for all chat rooms. All sessions are logged for later viewing, and these can also be made available to students.

\begin{tabular}{|l|l|}
\hline $\begin{array}{l}\text { Audio/Video } \\
\text { conferencing: }\end{array}$ & Audio/Video conferencing is available with the chat service. \\
\hline Whiteboard: & $\begin{array}{l}\text { There are several optional add-ons with whiteboard capabilities such as Elluminate } \\
\text { and DimDim. }\end{array}$ \\
\hline Asynchronous: & $\begin{array}{l}\text { Students can enable or disable posts to be sent to their email. Students can receive } \\
\text { posts by email as daily digests of subject lines or whole posts. They can subscribe to }\end{array}$ \\
\hline Discussion forums:
\end{tabular}




\begin{tabular}{|c|c|}
\hline & $\begin{array}{l}\text { forum RSS feeds. A spell-checker is available for student and instructor responses. } \\
\text { Granular roles system enables students to be set as administrator of individual } \\
\text { forums in a course. Instructors can allow students to create discussion groups. Posts } \\
\text { may be peer reviewed by other students. Instructors can view statistical summaries } \\
\text { of discussions displaying participation which can be used to generate grades. } \\
\text { Discussions can be shared across courses, departments, or any institutional unit. The } \\
\text { Q\&A forum requires students to post their perspectives before viewing other } \\
\text { students' postings. After the initial posting, students can view and respond to others' } \\
\text { postings. This feature allows equal initial posting opportunity among all students, } \\
\text { thus encouraging original and independent thinking. Students from different courses } \\
\text { can interact in system-wide chat rooms or discussion forums. }\end{array}$ \\
\hline File sharing: & $\begin{array}{l}\text { Students can submit assignments using drop boxes. They can upload files to their } \\
\text { blog and share them with other users via the blog. Instructors can make complete } \\
\text { copies of entire courses and/or individual items in courses, and share them with } \\
\text { other instructors or load them into one of the eCMS systems with Moodle } \\
\text { integration (Hive, Odalis, etc.). }\end{array}$ \\
\hline Internal e-mail: & $\begin{array}{l}\text { Students can use the built-in email functionality to email individuals or groups. } \\
\text { They can use a searchable address book. Instructors can email the entire class at } \\
\text { once at a single address or alias. Students can elect to forward their mail to an } \\
\text { external address. The Moodle messaging system can deliver mail either online or } \\
\text { via email. }\end{array}$ \\
\hline Online journal: & $\begin{array}{l}\text { Online journal used by millions of people around the world for self-expression and } \\
\text { communicating with family and friends. It is usually organized as a chronological } \\
\text { series of postings. Online journals usually are written by one person, although some } \\
\text { they can be authored by groups of people. }\end{array}$ \\
\hline \multicolumn{2}{|r|}{ 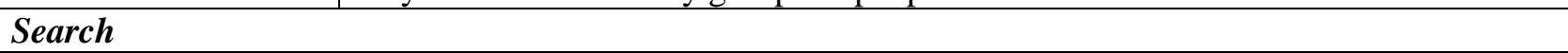 } \\
\hline $\begin{array}{l}\text { Metadata and } \\
\text { keyword search } \\
\text { engine: }\end{array}$ & $\begin{array}{l}\text { Students can search within the terms and keywords related to courses in the site also } \\
\text { can search within the glossary words. }\end{array}$ \\
\hline $\begin{array}{l}\text { Search within } \\
\text { courses: }\end{array}$ & $\begin{array}{l}\text { Students can search all course content. Students can search across all courses they } \\
\text { are enrolled in with a single search. They can search courses they are not enrolled } \\
\text { in. Search result can display course summaries and can display the text surrounding } \\
\text { the searched terms. }\end{array}$ \\
\hline $\begin{array}{l}\text { Calendar/ } \\
\text { Progress Review: }\end{array}$ & $\begin{array}{l}\text { Instructors and students can post events in the online course calendar also can post } \\
\text { announcements to a course announcement page. Students have a personal home } \\
\text { page that lists all courses in which the student is enrolled, new email and all course } \\
\text { and system-wide events from their personal calendar. Events are added to the } \\
\text { calendar, and can be aimed at individual users, your defined groups, or your } \\
\text { courses. Adding closing dates to assignments, forums, quizzes, etc. will cause them } \\
\text { to show up in the calendar block. }\end{array}$ \\
\hline Student profile: & $\begin{array}{l}\text { Students can create a personal home page in each course. Students have a home } \\
\text { page where their blog and personal calendar can be displayed. Custom blocks can } \\
\text { be created to show other information. }\end{array}$ \\
\hline Work offline: & $\begin{array}{l}\text { Students can benefit from the materials offered by instructors to get the knowledge } \\
\text { offline. They don't need to be online all the time. Instructors can make assignments } \\
\text { offline by downloading them and then submitting them for instructors by email. }\end{array}$ \\
\hline
\end{tabular}

\begin{tabular}{|l|l|}
\hline C. Instructor Tools (Course Development): \\
\hline $\begin{array}{l}\text { Online editor for } \\
\text { course organization: }\end{array}$ & $\begin{array}{l}\text { Instructors can organize learning objects, course tools, and content into learning } \\
\text { sequences that are reusable. They can create linear learning sequences organized } \\
\text { hierarchically by course, lesson, and topic and can reuse courses as templates for } \\
\text { future lessons. Instructors can assign students to groups. Each group can have its } \\
\text { own discussion forum and can have its own chat or whiteboard. }\end{array}$ \\
\hline Online quiz editor: & $\begin{array}{l}\text { Teachers can define a database of questions for re-use in different quizzes. } \\
\text { Questions can be stored in categories for easy access, and these categories can be } \\
\text { "published" to make them accessible from any course on the site. Quizzes can have }\end{array}$ \\
\hline
\end{tabular}




\begin{tabular}{|l|l|}
\hline & $\begin{array}{l}\text { a limited time window outside of which they are not available. At the teacher's } \\
\text { option, quizzes can be attempted multiple times, and can show feedback and/or } \\
\text { correct answers. Quiz questions and quiz answers can be shuffled (randomized) to } \\
\text { reduce cheating. Questions allow HTML and images. They can be imported from } \\
\text { external text files. Quizzes can be attempted multiple times, if desired. Attempts can } \\
\text { be cumulative, if desired, and finished over several sessions. Multiple-choice } \\
\text { questions supporting single or multiple answers. Short Answer questions (words or } \\
\text { phrases). True-False questions Matching questions. Random questions. Numerical } \\
\text { questions (with allowable ranges). Embedded-answer questions (cloze style) with } \\
\text { answers within passages of text. Embedded descriptive text and graphics. }\end{array}$ \\
\hline Grade distribution: & $\begin{array}{l}\text { Moodle allows a grade distribution tool for each group of students in specific } \\
\text { course. Instructors can benefit from the useful statistics about the grades and. }\end{array}$ \\
\hline
\end{tabular}

\begin{tabular}{|c|c|}
\hline \multicolumn{2}{|c|}{ D. Course and Curriculum Design: } \\
\hline Automated testing: & $\begin{array}{l}\text { The system can randomize the questions and answers. Instructors can create self- } \\
\text { assessments and set a time limit on a test. They can permit multiple attempts. The } \\
\text { students are allowed to review past attempts of a quiz. Instructors can specify } \\
\text { whether correct results are shown as feedback. The system supports Remote Quiz } \\
\text { Protocol which allows questions to be rendered and scored externally to the system } \\
\text { via standards-based web services. It supports latex rendering of mathematical } \\
\text { equations. Test types allows in Moodle: Multiple choice, Multiple answer, } \\
\text { Matching, Ordering, Jumbled sentence, Calculated, Fill-in the blank, Short answer, } \\
\text { and Essay, Questions can contain other media elements (images, videos, audio). } \\
\text { Teachers can define a database of questions for re-use in different quizzes. }\end{array}$ \\
\hline Online grading: & $\begin{array}{l}\text { Quizzes are automatically graded, and can be re-graded if questions are modified. } \\
\text { Instructors can choose to mark each student on all questions or to mark each } \\
\text { question on all students. When an instructor adds an assignment to the course, the } \\
\text { software automatically adds it to the grade-book. Instructors can add grades for } \\
\text { offline assignments. }\end{array}$ \\
\hline Course templates: & $\begin{array}{l}\text { The software provides support for template-based course creation. Course content } \\
\text { may be uploaded through WebDAV. The system allows administrators to use an } \\
\text { existing course or a pre-defined template as a basis for a new course. Instructors can } \\
\text { reuse courses as templates for future lessons. }\end{array}$ \\
\hline $\begin{array}{l}\text { Curriculum } \\
\text { management: }\end{array}$ & $\begin{array}{l}\text { Instructors can organize learning objects, course tools, and content into learning } \\
\text { sequences that are reusable. Instructors can create linear learning sequences } \\
\text { organized hierarchically by course, lesson, and topic. Instructors can reuse courses } \\
\text { as templates for future lessons. }\end{array}$ \\
\hline $\begin{array}{l}\text { Customize look and } \\
\text { feel: }\end{array}$ & $\begin{array}{l}\text { The system provides default course look and feel templates. Instructors can change } \\
\text { the navigation icons and color schemes for a course. They can change the order and } \\
\text { name of menu items for a course. Institutions can create their own look and feel } \\
\text { templates across the entire system, including their own institutional logos, headers, } \\
\text { and footers. The system can support multiple institutions, departments, schools or } \\
\text { other organizational units on a single installation where each unit can apply its own } \\
\text { look and feel templates as well as institutional images, headers and footers. }\end{array}$ \\
\hline Automated glossary: & $\begin{array}{l}\text { This activity allows participants to create and maintain a list of definitions, like a } \\
\text { dictionary. The entries can be searched or browsed in many different formats. The } \\
\text { glossary also allows teachers to export entries from one glossary to another (the } \\
\text { main one) within the same course. Allows participants to create and maintain a list } \\
\text { of definitions, like a dictionary. Student entries can be previewed by instructors } \\
\text { before publishing. Entries can be searched or browsed using alphabet, category, } \\
\text { date, and author. }\end{array}$ \\
\hline
\end{tabular}

E. Administrator Tools:

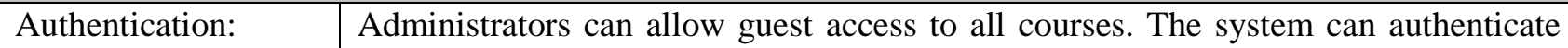
against an external LDAP server and also authenticate using the Kerberos protocol. The system supports Shibboleth, supports the Central Authentication Service (CAS) and it can support multiple organizational units and virtual hosts within a server 


\begin{tabular}{|l|l|}
\hline & $\begin{array}{l}\text { configuration. Different users can have different authentication settings. The } \\
\text { Moodle Network enables different servers to join in trust relationships to provide } \\
\text { single sign-on between Moodle sites. }\end{array}$ \\
\hline $\begin{array}{l}\text { Course } \\
\text { Authorization: }\end{array}$ & $\begin{array}{l}\text { The system supports restricting access based on roles and roles can also be } \\
\text { customized by the service provider. Administrators can create an unlimited number } \\
\text { of custom organizational units and roles with specific access privileges to course } \\
\text { content and tools. They can distribute the permissions and roles across multiple } \\
\text { institutions or departments hosted in the server environment. Instructors or students } \\
\text { may be assigned different roles in different courses. }\end{array}$ \\
\hline Validation of input: & It is available for some entries. \\
\hline $\begin{array}{l}\text { Automated } \\
\text { registration: }\end{array}$ & $\begin{array}{l}\text { Instructors can add students to their courses manually or allow students to self- } \\
\text { register. They can batch add students to the system using a delimited text file and } \\
\text { can transfer student information bidirectional between the system and an SIS using } \\
\text { delimited text files. The software supports data interchange with student } \\
\text { information systems through an event-driven API. }\end{array}$ \\
\hline $\begin{array}{l}\text { Course creation, } \\
\text { duplication, and } \\
\text { deletion: }\end{array}$ & $\begin{array}{l}\text { Instructors can create, edit, duplicate, any one of their course. The administrator } \\
\text { also can do the same. }\end{array}$ \\
\hline $\begin{array}{l}\text { Course and web site } \\
\text { back-up: }\end{array}$ & $\begin{array}{l}\text { Moodle has a course backup and restore process. Each successive version has } \\
\text { offered more options in this process. Many Moodle site administrators turn on an } \\
\text { automated backup function, which does a full course backup on a schedule. The on } \\
\text { demand backup and restore functions can be found in the administrative block of a } \\
\text { course. }\end{array}$ \\
\hline Statistics: & Usage of statistics can be aggregated across courses or across the institution. \\
\hline $\begin{array}{l}\text { First and last access } \\
\text { date for courses: }\end{array}$ & $\begin{array}{l}\text { Instructors can get reports showing the number of times, time, date, frequency and } \\
\text { IP address of each student who accessed course content, discussion forums, course } \\
\text { assessments, and assignments. }\end{array}$ \\
\hline
\end{tabular}

\begin{tabular}{|l|l|}
\hline F. Technical Specification: \\
\hline Hardware/Software & All major web browsers work fine. \\
\hline $\begin{array}{l}\text { Client browser } \\
\text { required: }\end{array}$ & $\begin{array}{l}\text { The system supports Oracle. The system supports MS SQL Server, MySQL, or } \\
\text { PostGreSQL. The application requires only one database and can coexist with tables } \\
\text { from other applications. }\end{array}$ \\
\hline Database required: & $\begin{array}{l}\text { A Unix version is available - The software is available for most variants of Linux or } \\
\text { Unix. }\end{array}$ \\
\hline UNIX server: & $\begin{array}{l}\text { A Windows version is available - The software is available for a variety of } \\
\text { Windows web servers. }\end{array}$ \\
\hline Windows server: & $\begin{array}{l}\text { Students can access context sensitive help for any tool. The system includes online } \\
\text { tutorials which may help students learn how to use the system. }\end{array}$ \\
\hline Help desk: & $\begin{array}{l}\text { Moodle offers over 70 languages. } \\
\text { Multi-languages } \\
\text { support: }\end{array}$ \\
\hline Pricing/Licensing & $\begin{array}{l}\text { Moodle.org is an open source community launched in 2001 that has grown out of a } \\
\text { PhD research project by Martin Dougiamas. Version 1.0 was released on August 20, } \\
\text { 2002. Moodle.com is a company launched in 2003 that sponsors Moodle } \\
\text { development and provides commercial support, hosting, custom development, and } \\
\text { consulting. The Moodle Partners are a network of companies that work with } \\
\text { Moodle.com to provide services around the world. }\end{array}$ \\
\hline Company profile: \\
\hline Free \\
\hline Cost:
\end{tabular}




$\begin{array}{ll}\text { Product Name: } & \text { Blackboard } \\ \text { Company: } & \text { Blackboard Inc. } \\ \text { URL: } & \text { http://www.blackboard.com/ } \\ \text { Developer: } & \text { Blackboard } \\ \text { Contact Developer: } & \text { For sales inquiries, call: (800) 424-9299, ext. } 4\end{array}$

\begin{tabular}{|l|l|}
\hline Feature Name & Description
\end{tabular}

\begin{tabular}{|l|l|}
\hline A. Pedagogical Factor (learner and instructor view): \\
\hline $\begin{array}{l}\text { View course } \\
\text { objectives: }\end{array}$ & $\begin{array}{l}\text { It offers a frame to view the course objectives. Instructors can assign the objectives } \\
\text { of each course they instruct. }\end{array}$ \\
\hline $\begin{array}{l}\text { View course } \\
\text { activities: }\end{array}$ & $\begin{array}{l}\text { It offers a frame to view the course activities. Instructors can assign the activities } \\
\text { that should be done by students for each course they instruct. }\end{array}$ \\
\hline Feedback for users: & $\begin{array}{l}\text { The Feedback module allows you to create and conduct surveys to collect feedback } \\
\text { from Students. Blackboard offers useful feedback for instructors. }\end{array}$ \\
\hline $\begin{array}{l}\text { Self-assessing for } \\
\text { students: }\end{array}$ & $\begin{array}{l}\text { Instructors can create self-assessments for their students enrolled in the courses. } \\
\text { They can provide personalized comments for essay/short answer questions, and can } \\
\text { add comments to assessment results. }\end{array}$ \\
\hline $\begin{array}{l}\text { Students' progress } \\
\text { tracking and } \\
\text { monitoring for } \\
\text { teachers: }\end{array}$ & $\begin{array}{l}\text { Instructors can track the frequency and duration of student access to individual } \\
\text { course components. They can get reports showing the time and date and frequency } \\
\text { students as an aggregated group accessed course content. They also can get reports } \\
\text { showing the number of times, time, date, frequency and IP address of each student } \\
\text { who accessed course content, discussion forums, course assessments, and } \\
\text { assignments. Students who appear to be at risk can be notified within the system, } \\
\text { and such notifications are tracked. }\end{array}$ \\
\hline
\end{tabular}

\section{B. Learner Environment:}

\section{Communication}

Synchronous:

Real-time chat room: $\quad$ The chat tool supports unlimited simultaneous group discussions and students can create new rooms. Instructors may moderate chats and suspend students from the chat rooms. The chat tool supports a structured way for students to ask questions and instructors to provide answers. The system creates archive logs for all chat rooms. The Java-based chat tool supports unlimited simultaneous group discussions and private messages. Instructors may moderate chats and suspend students from the chat rooms. Instructors can view chat logs and share these with students. The virtual classroom tool supports a structured way for students to ask questions and instructors to provide answers.

\begin{tabular}{l|l}
\hline Audio/Video & Audio/Video conferencing is available with the chat service.
\end{tabular}

conferencing:

Whiteboard:

The whiteboard supports image and PowerPoint uploading and also supports mathematical symbols. The software supports group web browsing and application desktop sharing. It can archive a recording of whiteboard sessions for future viewing. The software supports a whiteboard that can have multiple instances in the same course and also supports mathematical symbols, image and PowerPoint uploading. In addition it supports group web browsing and can archive a recording of whiteboard sessions for future viewing.

Asynchronous:

Discussion forums:

A spell-checker is available for student and instructor responses. Discussions can be viewed by date, thread, or poster. Discussion threads are expandable and collapsible to view an entire conversation on one screen. Discussion threads can be searched. Posts can contain URLs, file attachments and may contain HTML. The discussion software includes a formatting text editor which can create mathematic equations. Instructors can allow students to create discussion groups. Instructors can view statistical summaries of discussions displaying participation which can be used to generate grades. 


\begin{tabular}{|c|c|}
\hline File sharing: & $\begin{array}{l}\text { Students can submit assignments using drop boxes. They can share the contents of } \\
\text { their personal folders with other students. They have a private folder into which } \\
\text { they can upload and download files. Students can upload files to a shared group } \\
\text { folder and can submit assignments using drop boxes. Instructors can upload files to } \\
\text { the personal folder of a student. }\end{array}$ \\
\hline Internal e-mail: & $\begin{array}{l}\text { Students can use the built-in email functionality to email individuals or groups. } \\
\text { They can use a searchable address book. Instructors can email the entire class at } \\
\text { once at a single address or alias. Also, they can use Blackboard Messages (internal } \\
\text { email) to email individuals, groups, or all users with a specific role in their courses. } \\
\text { Students can attach files to emails, and emails can contain URLs, file attachments } \\
\text { and may contain HTML. }\end{array}$ \\
\hline Online journal: & Students can make private notes about their course. \\
\hline \multicolumn{2}{|r|}{ 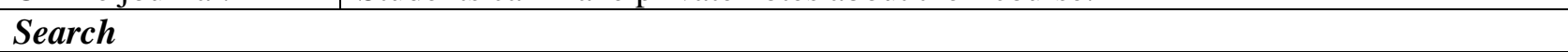 } \\
\hline $\begin{array}{l}\text { Metadata and } \\
\text { keyword search } \\
\text { engine: }\end{array}$ & $\begin{array}{l}\text { Students can search within the terms and keywords related to courses in the site } \\
\text { enrolled in, also can search within the glossary words. }\end{array}$ \\
\hline $\begin{array}{l}\text { Search within } \\
\text { courses: }\end{array}$ & $\begin{array}{l}\text { Students can search all discussion threads and search chat or virtual classroom } \\
\text { session recordings. They can search all Discussion Boards, as well as chat or virtual } \\
\text { classroom session recordings by name or dates. }\end{array}$ \\
\hline $\begin{array}{l}\text { Calendar/ } \\
\text { Progress Review: }\end{array}$ & $\begin{array}{l}\text { Instructors and students can post events in the online course calendar. They can post } \\
\text { announcements to a course announcement page and have a personal home page that } \\
\text { lists all courses, in which the student is enrolled, new email and all course and } \\
\text { system-wide events from their personal calendar. Students can view their grades on } \\
\text { completed assignments, total points possible, course grade, and compare their } \\
\text { grades against the class performance. }\end{array}$ \\
\hline Student profile: & $\begin{array}{l}\text { Students can create a personal home page in each course. They can create a personal } \\
\text { home page which may include a photo, personal information. }\end{array}$ \\
\hline Work offline: & $\begin{array}{l}\text { Students can compile and download the content for an entire course into a format } \\
\text { that can be printed or stored locally. Instructors can publish course content on a CD- } \\
\text { ROM that can be linked to dynamically from within the online course or viewed } \\
\text { offline. Students can download course content and discussion group content with a } \\
\text { PDA. }\end{array}$ \\
\hline
\end{tabular}

\section{Instructor Tools (Course Development):}

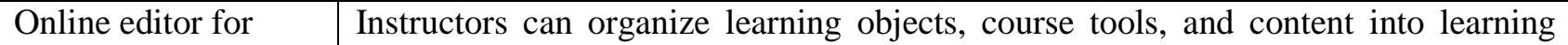
course organization: $\quad$ sequences that are reusable. They can create linear learning sequences organized hierarchically by course, lesson, and topic. They can reuse courses as templates for future lessons. They also can create both linear and nonlinear learning sequences using a content library. Instructors can access information and tips and tutorials on instructional design and on creating a collaborative learning environment. The product provider also offers instructional design services for a fee to help instructors create their courses.

Online quiz editor: $\quad$ Teachers can define a database of questions for re-use in different quizzes. Quiz questions and quiz answers can be randomized to reduce cheating.

Grade distribution: $\quad$ Blackboard allows a grade distribution tool for each group of students in specific course. Instructors can benefit from the useful statistics about the grades.

\section{Course and Curriculum Design:}

Automated testing: $\quad$ The system can randomize the questions and answers. Instructors can create selfassessments and can set a time limit on a test. They can permit multiple attempts. The students are allowed to review past attempts of a quiz. Instructors can set dates and times when students must access tests. Instructors can create extra-credit questions that can be scored separately and differentially weigh tests and create grading rules. They can choose which attempt(s) are to include in the grade calculations. Instructors can override the automated scoring and determine how to communicate test results to students. Test types available in Blackboard are: 


\begin{tabular}{|c|c|}
\hline & $\begin{array}{l}\text { Multiple choice, Multiple answer, Matching, Ordering, Jumbled sentence, } \\
\text { Calculated, Fill-in the blank, Short answer, Survey questions, and Essay. Questions } \\
\text { may contain other media elements (images, videos, audio). Instructors can create } \\
\text { question pools, and export and import those pools. The system provides analysis } \\
\text { data for surveys and test item results can be exported for analysis. }\end{array}$ \\
\hline Online grading: & $\begin{array}{l}\text { Instructors and teaching assistants can mark paragraph questions, and mark and } \\
\text { return assignments turned in through the assignment drop-box. They can provide } \\
\text { feedback on all assignments through annotations. Instructors can publish student } \\
\text { submissions as examples for other students to see. When an instructor adds an } \\
\text { assignment to the course, the software automatically adds it to the grade-book. } \\
\text { Besides, instructors can add grades to offline assignments and add details to the } \\
\text { grade-book in custom columns. They also can create a course grading scale that } \\
\text { may employ raw scores, percentages, letter grades or pass/fail metrics. Instructors } \\
\text { can download the results of a test across sections of a course and across semesters, } \\
\text { aggregate data and perform item-level analysis of individual survey items across the } \\
\text { entire system. }\end{array}$ \\
\hline Course templates: & $\begin{array}{l}\text { The software provides support for template-based course creation. The system } \\
\text { provides course design wizards that provide step-by-step guides that take faculty } \\
\text { and course designers through the completion of common course tasks, such as } \\
\text { setting up the course homepage, syllabus, organizer pages, content modules, and } \\
\text { discussion. The system allows administrators to use an existing course or a pre- } \\
\text { defined template as a basis for a new course. Instructors can use templates to create } \\
\text { course content. The templates include a rich text content editor. Instructors can } \\
\text { categorize course content as announcements, calendar entries, course units, } \\
\text { discussion forums, handouts, instructor biography, lecture notes, links, syllabus and } \\
\text { course descriptions, tips, FAQs and resources. }\end{array}$ \\
\hline $\begin{array}{l}\text { Curriculum } \\
\text { management: }\end{array}$ & $\begin{array}{l}\text { Instructors can selectively release assignments, assessments, and announcements } \\
\text { based on specific start and stop dates. Instructors can release materials based on a } \\
\text { single criteria (date, grade, etc.) or instructors can use Boolean expressions to } \\
\text { identify multiple selective release criteria, can set up specific course content that is } \\
\text { released on a specific date and must be completed by students before they continue } \\
\text { with the course, can link discussions to specific dates or course events, can } \\
\text { personalize access to specific course materials based on group membership, can } \\
\text { personalize access to specific course materials based on previous course activity, } \\
\text { and can personalize access to specific course materials based on student } \\
\text { performance. }\end{array}$ \\
\hline $\begin{array}{l}\text { Customize look and } \\
\text { feel: }\end{array}$ & $\begin{array}{l}\text { The system provides default course look and feel templates. Instructors can change } \\
\text { the navigation icons and color schemes for a course. They can change the order and } \\
\text { name of menu items for a course and can create their own look and feel templates } \\
\text { across the entire system, including their own institutional logos, headers, and } \\
\text { footers. Institutions can apply their own institutional images, headers and footers } \\
\text { across all courses. Instructors can change the navigation icons and color schemes } \\
\text { and the order, name, and function of menu items for a course. }\end{array}$ \\
\hline
\end{tabular}

E. Administrator Tools:

Authentication:

Administrators can allow guest access to all courses. The system can authenticate against an external LDAP server, can authenticate using the Kerberos protocol, supports Shibboleth, supports the Central Authentication Service (CAS), and can authenticate against IMAP, POP3 or secure NNTP. Administrators can set up failthrough authentication against a secondary source (e.g. the system's own database) in the event that the primary source (e.g. LDAP server) fails. They also can set courses to be publicly accessible or protect access to individual courses with a username and password. The system can also authenticate against an external LDAP server, Active Directory, Microsoft's .NET Passport Web Service, or using other protocols (Kerberos, CAS and Shibboleth have been implemented). SIF is compatible. 


\begin{tabular}{|c|c|}
\hline $\begin{array}{l}\text { Course } \\
\text { Authorization: }\end{array}$ & $\begin{array}{l}\text { The system supports restricting access based on roles and roles can also be } \\
\text { customized by the service provider. Instructors or students may be assigned } \\
\text { different roles in different courses. Administrators can create an unlimited number } \\
\text { of custom organizational units and roles with specific access privileges to course } \\
\text { content and tools. Instructors or students may be assigned different roles in different } \\
\text { courses. Administrators and Instructors can assign different levels of access to the } \\
\text { system or to specific courses based on pre-defined roles. The system can access } \\
\text { authorization information stored in an LDAP directory. }\end{array}$ \\
\hline Validation of input: & It is available for some entries. \\
\hline $\begin{array}{l}\text { Automated } \\
\text { registration: }\end{array}$ & $\begin{array}{l}\text { Instructors can add students to their courses manually or allow students to self- } \\
\text { register. Administrators can batch add students to the system using a delimited text } \\
\text { file. Administrators and Instructors can batch add students to a course using a } \\
\text { delimited text file or students can self-register. Administrators can batch create } \\
\text { courses, users, and enrollments in the system. The software supports integration } \\
\text { with student information systems through an event-driven API or through their tool } \\
\text { which is based on scheduled system extracts. Administrators can transfer student } \\
\text { information bi-directionally between the system and an SIS in batch or in real time. }\end{array}$ \\
\hline $\begin{array}{l}\text { Course creation, } \\
\text { duplication, and } \\
\text { deletion: }\end{array}$ & $\begin{array}{l}\text { Instructors can create, edit, and duplicate any of their courses. The administrator can } \\
\text { also do the same. }\end{array}$ \\
\hline $\begin{array}{l}\text { Course and web site } \\
\text { back-up: }\end{array}$ & $\begin{array}{l}\text { Administrators or instructors with appropriate permissions can use the backup } \\
\text { restore functions to create, transfer or restore parts of an existing course or a whole } \\
\text { course. }\end{array}$ \\
\hline Statistics: & Usage of statistics can be aggregated across courses or across the institution. \\
\hline $\begin{array}{l}\text { First and last access } \\
\text { date for courses: }\end{array}$ & $\begin{array}{l}\text { Instructors can get reports showing the number of times, time, date, frequency and } \\
\text { IP address of each student who accessed course content, discussion forums, course } \\
\text { assessments, and assignments. }\end{array}$ \\
\hline
\end{tabular}

\begin{tabular}{|l|l|}
\hline \multicolumn{2}{|l|}{ F. Technical Specification: } \\
\hline Hardware/Software \\
\hline $\begin{array}{l}\text { Client browser } \\
\text { required: }\end{array}$ & $\begin{array}{l}\text { For the Windows 2000 operating system, the following browsers are compatible: IE } \\
\text { 6.0, Netscape 7.1 and 8.0, and Firefox 1.0. For Windows XP, the following } \\
\text { browsers are compatible: IE 6.0 and 7.0, Netscape 7.1 and 8.0, and Firefox 1.0. For } \\
\text { Mac OS 10.2, 10.3, and 10.4, compatible browsers include: IE 5.2, Netscape 7.1, } \\
\text { Firefox 1.0, Safari 1.1,1.2 and 1.3. A full browser matrix is available. }\end{array}$ \\
\hline Database required: & The system supports Oracle and MS SQL Server. \\
\hline UNIX server: & A Unix version is available. \\
\hline Windows server: & A Windows version is available \\
\hline Technical Support & $\begin{array}{l}\text { The system includes online tutorials that may help students learn how to use the } \\
\text { system. Students can access online tutorials, a student manual, the product } \\
\text { knowledge base, and the product reference center. }\end{array}$ \\
\hline $\begin{array}{l}\text { Help desk: } \\
\text { support: }\end{array}$ & $\begin{array}{l}\text { Blackboard Academic Suite is fully internationalized and is available in 8 languages } \\
\text { including language packs for English, Spanish, Italian, French, Simplified Chinese } \\
\text { Japanese, Portuguese and German. A language pack editor enables clients to create } \\
\text { their own language packs or edit existing languages and share them with their peers. }\end{array}$ \\
\hline Pricing/Licensing & $\begin{array}{l}\text { Founded in 1997, Blackboard is a public company (NasdaqNM:BBBB) that has } \\
\text { over the years acquired CourseInfo, Web-Course-in-a-Box, Prometheus, and } \\
\text { WebCT CMSs. The Company's product line consists of the Blackboard Academic } \\
\text { Suite (including the Blackboard Learning System, Blackboard Community System, } \\
\text { and Blackboard Content System) and the Blackboard Commerce Suite. Blackboard } \\
\text { is headquartered in Washington, D.C. }\end{array}$ \\
\hline Company profile: \\
$\begin{array}{l}\text { The annual license fee is based on FTE students in an institution (or school within } \\
\text { an institution) or consortium. In some markets, the annual license fee is determined } \\
\text { on a per-user basis. }\end{array}$ \\
\hline Cost:
\end{tabular}




\section{References}

Aberdour M. (2007). Open Source Learning Management Systems. Retrieved April. 14, 2010, from http://www.epic.co.uk/content/news/oct_07/whitepaper.pdf

Adams M., Altany A., Faircloth V., Franke T., Higgins S., Houghton B., Nixon M., Venturo L., Vihnanek E. (December 5, 2002). WebCT vs. Blackboard: Report of the Course Management Task Force. Retrieved April 30, 2010, from http://www.wcu.edu/it/cio/planning/cmsfinalreport.pdf

Berg K. (August, 2005). Finding Open options: An Open Source software evaluation model with a case study on Course Management Systems. Master Thesis, Telburg University. Retrieved May 1, 2010, from http://www.karinvandenberg.nl/Thesis.pdf

Blackboard Learning Management System. Retrieved April 28, 2010, from http://www.blackboard.com/

Bremer D. and Bryant R. (2005). A Comparison of Two Learning Management Systems: Moodle vs. Blackboard. Retrieved May 4, 2010, form http://www.naccq.ac.nz/conference05/proceedings_05/ concise/bremer_moodle.pdf

Moodle, Free Open Source Course Management System. Retrieved April 28, 2010, from http://www.moodle.org

Open Source Initiative. http://www.opensource.org/

Open source listed at UNESCO. Retrieved April 28, 2010, from http://www.unesco.org/

WebCT Learning Management System. Retrieved April 28, 2010, from http://www.webct.com/webct/ 